\title{
Globalized Socialism, Nationalized Time: Soviet Films, Albanian Subjects, and Chinese Audiences across the Sino-Soviet Split
}

\author{
Elidor Mëhilli
}

To the northeast of the city center in Tirana, Albania's capital, rises a building that was once an expression of national glory. Years of neglect, however, have taken a toll. Recently, the Ministry of Culture decided to move in, so officials ordered a renovation. The resulting facelift has buried some of the communist-era symbols under a thick layer of white paint. Still, it is hard to miss the hallmarks of late Stalinist architecture: the ornamental gate, the entrance with its Corinthian columns, the emblem of the People's Republic emblazoned on the pediment. Three sculptural figures loom above: a male and a female dressed in traditional garb, flanking a central female character raising a torch to the sky (it was once a star, but renovators reportedly opted for a more western-friendly version). This is the official birthplace of Albanian cinema.

Established in 1952, the country's film studio was based on a Soviet design, which explains the neoclassical façade. Authorities baptized it Shqipëria e Re (New Albania). Residents no longer refer to it by that name, instead simply calling it Kinostudio. On one level, this was the almost-magical seat of a national project: the point of origin for many postwar careers, the source of mass entertainment and the first motion pictures, the first reels that defined many childhoods. That building sought to produce, as the art historian Gëzim Qëndro put it, "a map of reality" under socialism. ${ }^{1}$ On another, it was a manifestly Soviet product of the 1950s, as the architecture attests, offering an opportunity to consider how international engagement produced a national icon.

This article explores Cold War-era filmmaking as a window into collaboration and confrontation across the Sino-Soviet split. Over two decades, a small Balkan country became a site of cross-continental exchange between local planners, Soviet advisers, and, later on, Chinese collaborators. Briefly a Yugoslav satellite after the Second World War, Albania then embraced Stalinism in the 1950s, only to switch allegiances again during the dramatic early 1960s Moscow-Beijing dispute. This shift implicated party functionaries, government administrators, cultural directors, and ambitious youths in worldwide developments, from early struggles over spheres of influence in the

The idea for this article came to me during a conversation with Chen Jian many years ago, while I held a Mellon fellowship at The George Washington University. I presented an earlier version at The Jordan Center for the Advanced Study of Russia at New York University. Thanks to Yanni Kotsonis, Joshua Tucker, and the participants, in particular Rossen Djagalov. I thank the conveners of this cluster, as well as the journal's editor and the anonymous reviewers, for their enthusiasm. Research in three countries was made possible by generous funding from Princeton University, the Presidential Awards at Hunter College of the City University of New York, and the PSC-CUNY Research Awards.

1. Gëzim Qëndro, Kinostudioja “Shqipëria e vjetër”: (Ose Aventura Seminale e Gjurmës) (Tirana, 2016), 251. 
Balkans to the advent of socialist disunity across Eurasia. A country on the edge of the capitalist and communist spheres is a good place to explore Cold War antagonism, but Albania also offers extraordinary access to ideological antagonism within the socialist world, including its various economic and cultural manifestations.

In tracing Soviet-Albanian-Chinese exchanges, my objective is to show that nationalizing and globalizing processes have been deeply intertwined. For the novice rulers of Albania-a country that declared independence in 1912, struggled to retain it, then lost it-nationalization was a matter of survival. The regime vowed to build a non-capitalist society but found itself economically dependent on bigger powers like Yugoslavia and the Soviet Union. Nationalization meant more than confiscating private property, devising central plans, and making up enemies. Films, newsreels, and documentaries could be instruments of self-definition too, especially in the context of high levels of illiteracy. It is useful, then, to think of this postwar self-definition as proceeding along three parallel lines: producing a usable past (against an Ottoman and more recent fascist background); mapping a socialist present (with the participation of Soviet actors and directors); and, ultimately, repositioning the country within a changing global map of revolutionary politics (thanks to China's anti-Soviet turn in the 1960s).

As discussions of socialism as a form of transnational exchange proliferate, it becomes necessary to spell out precisely how this exchange interacted with national imperatives over time. ${ }^{2}$ Within Balkan studies, nationalism often emerges as a driving force seemingly drowning alternative ideologiesespecially when compared to scholarship on central Europe, where national indifference now seems endemic. Rather than assuming nationalism's fullyformed presence, I show how geopolitics and transnational contact made forms of national assertion possible. Film is only one possible avenue for pursuing this kind of analysis, but it offers some advantages. First of all, a national film industry in Albania was a late development, requiring extensive imports. Soviet directors brought their reels and their plots to the Mediterranean, revealing how the Soviet civilizational blueprint could be used to tell a local story of heroic resistance, Ottoman backwardness, and western betrayal.

By the early 1960s, however, the Soviet-Albanian friendship was in ruins. From instruments of friendship, films became weapons in a battle over the soul of socialism. As Tirana turned to Beijing for support, Albanian films assumed unexpected meaning, especially during China's self-inflicted isolation of the Great Proletarian Cultural Revolution (1966-76). When seen as products of negotiation, then, films make it possible to consider the vision of those who made them, the interests and calculations of those who distributed them, and, ideally, problems of reception and interpretation. Analyzed in the specific context of geopolitical and ideological conflicts, they help bring into focus the role of cultural intermediaries (directors, editors, censors, and

2. Recent efforts include Patryk Babiracki and Kenyon Zimmer, eds., Cold War Crossings: International Travel and Exchange across the Soviet Bloc, 1940s-1960s (Arlington, 2014); and Anne E. Gorsuch and Diane P. Koenker, eds., The Socialist Sixties: Crossing Borders in the Second World (Bloomington, 2013). 
administrators of socialist taste), beyond the usual top-level powerbrokers that populate political histories of the Cold War. ${ }^{3}$

Specifically, this article spotlights the Sino-Soviet split not only as a rupture but as an opportunity to connect across a vast distance. Sino-Soviet disagreements played out at the highest party levels, and so Cold War scholars continue to scrutinize documents for clues into the rift, supplying elitedriven analyses. ${ }^{4}$ But a split in the socialist world was always bound to be more than an affair between Central Committees. We lack deep analyses of its far-reaching social consequences, especially from comparative and transnational perspectives. It is the aftermath of the rift that constitutes the pertinent story of how socialism's global fortunes came to be rearticulated. The 1960s provide an opportunity to consider the social history and the cultural dimensions of political disunity within international socialism. How did the schism structure new worldviews and categories of thinking? This, too, was a largescale offensive to redefine the proper ownership of a revolutionary legacy.

To my mind, a global perspective on this history would have to give a sense of the various scales at which socialism operated-large centers like Moscow and Beijing, with their Central Committees and planning bureaus, but also regional powers and assertive peripheries, internal ideological faultlines, and zones of contact that the Soviets (or, later, the Chinese) could not control. ${ }^{5}$ The new Cold War scholarship insists that the revolutionary battleground shifted to the Global South by the 1960s, but this overlooks the simple fact that revolutionary battles kept raging in the heart of Europe. ${ }^{6}$ A global perspective on the Cold War can also be an opportunity to capture the surprising

3. Cinematic exchanges have already illuminated dynamics between Soviet audiences and films from the so-called Third World: Rossen Djagalov and Masha Salazkina, “Tashkent '68: A Cinematic Contact Zone,” Slavic Review 75, no. 2 (Summer 2016): 279-98.

4. Recent contributions include, among others, Jeremy Scott Friedman, Shadow Cold War: The Sino-Soviet Competition for the Third World (Chapel Hill, 2016); Sergey Radchenko, Two Suns in the Heavens: The Sino-Soviet Struggle for Supremacy, 1962-1967 (Washington, 2009); and Lorenz M. Lüthi, The Sino-Soviet Split: Cold War in the Communist World (Princeton, 2008). Particularly revealing are the Sino-Soviet-east European encounters that populate Austin Jersild's The Sino-Soviet Alliance: An International History (Chapel Hill, 2014).

5. Global histories of socialism do not have to be all-encompassing, just as global accounts of the Cold War, even massive multi-volume ones, do not strive for totality. A case in point: Melvyn P. Leffler and Odd Arne Westad, eds., The Cambridge History of the Cold War, 3 vol. (New York, 2010). But how these histories are scaled affects the questions posed. On the problem of the dilution of the Cold War "as a complex and yet unified, identifiable subject of inquiry," see Federico Romero, "Cold War Historiography at the Crossroads," Cold War History 14, no. 4 (November 2014): 685-703. My approach is to work from the margin-both of the Cold War's European divide, and the related but separate global battle to define the contours of socialism. The margin is where these processes tensely overlapped, and thus a good place to test the limits of Moscow-centered (but also Beijing-centered) analyses.

6. For an imaginative approach to opening the "black box" of East German history in light of the Sino-Soviet split, see Quinn Slobodian, “The Maoist Enemy: China's Challenge in 1960s East Germany,” Journal of Contemporary History 51, no. 3 (July 2016): 635-59. Given the scope of the story, it is not surprising that it takes multiple authors to capture the variegated geography of a non-Soviet-centered socialism. Some examples are contained in Alexander C. Cook, ed., Mao's Little Red Book: A Global History (Cambridge Eng., 2014). 
reach of small states, specifically how ideological conflict endowed them with outsize significance. ${ }^{7}$ The outcome can be a suggestive view of socialism as containing multiple mental geographies and time regimes, and of socialist connectivity as paradoxical but also productive in unforeseen ways. In this specific instance, the nationalizing process that Soviet directors championed in 1950s Albania combined with the geopolitics of the Sino-Soviet split to create new, unanticipated possibilities for asserting one's place in the world.

Initially, Soviet directors found the story of local resistance against foreigners-fifteenth century to fascism-compelling. They celebrated Albanian militancy, the idea of an improbable state pursuing socialism at all costs. Still, they framed Albania as a socialist country-in the making, which was to say that it lagged behind. A decade later, cultural authorities sought to define a non-Moscow-centered way of being socialist in the world. As Albanian war films circulated around China, Mao Zedong hailed the small Balkan country as being ahead-the defiant protector of Marxism-Leninism and a revolutionary example to emulate. The outcomes of this shifting mental geography were unpredictable; the cultural reorientation from Moscow gradual and uneven. In cinema, for example, it meant allowing a spattering of (carefully screened) western films, rotating Soviet classics, and shipping Albanian war-themed films to China for mass dissemination. There, Cultural Revolution-era audiences encountered Albanian films as a small window into Europe (and hence, "the west").

To capture these zigzags over time, the article initially sketches Albania's shift from Belgrade to Moscow in 1948, which helps explain the zealous cultural promotion of the Soviet Union that followed it. The administration of films in this period reveals the profound challenge of bringing a national public into being. The analysis then shifts to how two Soviet directors engaged with Albania's Ottoman and fascist past, as well as its socialist present, seeing in their collaborative efforts a kind of mutual discovery in a Soviet key. Sergei Yutkevich and Il'ia Kopalin both addressed themes of struggle, but they worked in different genres and across a decade, making it possible to give a sense of the scope and evolution of socialist collaboration. The article's final section asks: What happens to socialist interconnectedness after the Moscow-Beijing schism? Championed by Moscow, Albania's emerging national cinema later found a captive audience in China under Mao Zedong, where it came to be celebrated as progressive, militant, and Marxist-Leninist. Earlier Soviet collaborations eventually fell from view, obscured by the writing of nationalized histories of filmmaking. Therefore, this article complements wide-ranging Albanian, Russian, and German archival sources with published and unpublished recollections, as well as contemporary press accounts.

7. Leverage against big powers has been typically recognized in the Third World, but it did not have to be confined to it. An important early agenda was set in David C. Engerman, "The Second World's Third World," Kritika: Explorations in Russian and Eurasian History 12, no.1 (Winter 2011): 183-211. 


\section{The Distance to Moscow}

Albania's Communist Party (renamed Party of Labor in 1948) came into being in 1941, with Yugoslav backing. On the one hand, Yugoslav involvement emboldened local leaders, who were inexperienced and prone to squabbling. On the other, it left Albania liberated from Nazi occupation, but also dependent on Belgrade for political and economic support. This helps explain why the cultural politics of the postwar period reflect a mixture of boundless euphoria and a sense of subordination. Authorities took possession of the tiny existing industries and workshops, and they also expropriated film theaters. ${ }^{8}$ They declared a monopoly on film trade, and set up a national agency to oversee production, imports, and distribution. Yet they could hardly feed the populace, let alone purchase foreign films, and so they relied on neighboring Yugoslavia to serve as a cultural conduit to the outside world. ${ }^{9}$ In short, the nationalization of the film industry, such as it was, preceded the creation of a national audience, just as the nationalization of the economy more broadly preceded the creation of a working class. This encouraged a sense of driving history forward, but also lagging behind.

Stalin initially approved of the Yugoslav tutelage over the smaller Balkan neighbor. But the conflict with Yugoslav leader Josip Broz Tito in 1948 unexpectedly created an opportunity for the Albanian regime to break free. Party leader Enver Hoxha, who relished the opportunity to deal directly with the Kremlin, declared loyalty to Stalin, whom he credited with having "saved" Albania from Yugoslav "colonization.” Explanations for the Soviet-Yugoslav schism center on the idea of a struggle over authority at the highest levels. Stalin had grown impatient and resentful of Tito's schemes for asserting power in the Balkans. He cut Tito loose, heaping scorn on his supporters as traitors to socialism, thus setting the stage for vicious trials of "Titoites" around the eastern bloc. ${ }^{10}$ But it is also possible to see this early moment of disunity in the Communist camp as a struggle over authority other than Stalin's. For Hoxha, the break meant an unprecedented opportunity to assert national authority over socialism. The country's window into the world expanded dramatically. In wartime (officially referred to as Lufta Antifashiste Nacionalçlirimtare, the

8. On pre-socialist precedents for "mobile cinemas" in the Balkans and interwar film culture in Vlorë, Korçë, Shkodër, and Tirana, see Karl Kaser, "Der Islam, Enver Hoxha und das albanische Kino: Umwege zur westlichen visuellen Moderne,” in Eckehard Pistrick, ed., Deutsch-Albanische Wissenschaftsbeziehungen hinter dem Eisernen Vorhang (Wiesbaden, 2016), 91-104 (esp. 93-96). For the capital in particular: Spiro Mëhilli, Arti i shtatë në Tiranë:(kinematë-filmat):ese (Tirana, 2011).

9. When officials asked Moscow for Soviet films and other materials in 1946, they specified that these be translated into Albanian or Serbian, since the populace did not understand Russian. "Iz dokladnoi zapiski referenta otdela vneshnei politiki TsK VKP(b) P.I. Manchkhi o poezdke v Albaniiu” (Secret), May 14, 1946, in Tat'iana V. Volokitina, T. M. Islamov; G.P. Murashko, A. F. Noskova, and L. A. Rogovaia, eds., Vostochnaia Evropa $v$ dokumentakh rossiiskikh arkhivov 1944-1953 gg., vol. 1, 1944-1948 gg. (Moscow, 1997), 434-38.

10. For an apt summary of the split and its implications, see Mark Kramer, "Stalin, the Split with Yugoslavia, and Soviet-East European Efforts to Reassert Control, 1948-1953,” in Timothy Snyder and Ray Brandon, eds., Stalin and Europe: Imitation and Domination, 1928-1953 (New York, 2014), 295-315. 
Anti-Fascist National Liberation War), the party had vowed to bring freedom from fascism. Now, it also declared freedom from Yugoslavia, blaming it for past repression and planning failures. It was a national breakthrough.

This schism allowed the regime to frame the year 1948 as a new beginning. ${ }^{11}$ Because the majority of Albanians were illiterate, non-print forms of communication (radio, rallies, newsreels) were crucial. Films could show illiterate individuals that they were not isolated in the world; that they enjoyed a partnership with the homeland of Lenin. In articulating this vision-in selecting Soviet films to be shown, in explaining them, transforming them into intelligible narratives-an insecure regime could project strength. By some official accounts, the spread of Soviet films increased in the late 1940s. One source put the number of Soviet screenings in 1946 at 3,697. Three years later, it had reached 8,700. The viewing audience had reportedly more than doubled. ${ }^{12}$ Considered in isolation, however, such numbers can be misleading. Official figures reported total screenings, but they did not specify where and when they took place. As with other areas of the central plan, screenings were arranged according to annual targets, as were audience numbers. Yet this was a rural country with a limited road network and electric grid. Even if we allow that a large increase in the number of Soviet film screenings took place after 1948, it hardly means that exposure was uniform.

The Society for Soviet-Albanian Friendship was the main instrument for familiarizing audiences with the Soviet Union. It was also an important vehicle for distributing Soviet films, since it administered mobile film projectors donated by the Vsesoiuznoe obshchestvo kul'turnykh sviazei s zagranitsei (All-Union Society for Cultural Ties Abroad). ${ }^{13}$ The Society's journal hailed Soviet cinema as the international vanguard, favourably comparing it to "the

11. Culture officials blamed Belgrade for past failures. An annual report from the Arts and Culture Committee, for example, justified the underdevelopment of the film industry by pointing to Yugoslav "sabotage." Koçi Xoxe, the interior minister who now stood accused as a pro-Yugoslav element, received blame for having overlooked the arts. See: Arkivi Qendror Shtetëror (hereafter AQSH), f. 490, v. 1948, dos. 811, fl. 14-17. (Arts and Culture Committee to Office of Prime Minister, January 29, 1949).

12. "Populli jonë mëson vazhdimisht nga Bashkimi Sovietik [sic]," Shqipëri B.R.S.S., no. 21 (September 1949): 23. By 1950, Albania had around 40 film theaters. Since 1945, it had received 452 Soviet films, documentaries, and newsreels. A survey of cultural affairs is contained in AQSH, f. 513, v. 1950, dos. 18, fl. 18-23. I do not focus on non-Soviet films here because they constituted a small share of screenings. According to a 1954 Soviet memo, over 90 percent of screenings consisted of Soviet titles: Rossiiskii gosudarstvennyi arkhiv noveishei istorii (hereafter RGANI), f. 5, op. 28, d. 153, 1. 55 (Ideologicheskoe rukovodstvo Albanskoi Partii Truda razvitiem nauki, kul'tury i iskusstva, June 30, 1954 [Secret]). There were, however, big exceptions like Raj Kapoor's Awāra (The Vagabond, 1951), which later became a sensation in Albania, as it did in the Soviet Union. See Sudha Rajagopalan, Indian Films in Soviet Cinemas: The Culture of Movie-going after Stalin (Bloomington, 2008), ch. 2.

13. For the earlier years of VOKS, see Michael David-Fox, Showcasing the Great Experiment: Cultural Diplomacy and Western Visitors to the Soviet Union, 1921-1941 (New York, 2011). For the later years, see Gosudarstvennyi Arkhiv Rossiiskoi Federatsii (hereafter GARF), f. 9576, op. 4, d. 1, 11. 85-87 (General'nomu Sovetu Obshchestva Druzhby 'Albaniia-Sovetskii Soiuz',' March 27, 1958). 
gangsters" and "decadence" of Hollywood. ${ }^{14}$ It highlighted, in particular, the reception of Soviet reels among villagers, whose worldview could expand through imported technology. ${ }^{15}$ But it is precisely because such rural events were rare that agitators deliberately emphasized them in this fashion. In 1954, the Soviet embassy admitted that almost half of the viewers of Soviet films were in the six largest cities, whereas the far more populous periphery had limited access to screenings. ${ }^{16}$ Uneven exposure to Soviet films, in other words, went parallel with efforts to nationalize a viewing public that was still geographically divided.

The fact that big cities were the most conspicuous sites of "friendship work" made agitators obsess over the countryside. ${ }^{17}$ As we will see, a couple of Soviet directors also addressed this problem-the quest to bring a national audience into being. The challenge was not solely one of resources. Imported films were subject to the authority of several offices, reflecting the interlocking spheres of the party-state. They were initially under the purview of Komiteti i Arteve dhe Kulturës (Arts and Culture Committee). This was a modest organization, forced to rely on Albanian diplomats abroad to sign bilateral agreements with the respective "people's democracies." 18 Film administrators, moreover, had to coordinate with the party's Central Committee (specifically, with its agitprop and foreign sectors). Overburdened with problems of grain shipments, loan rates, and spare parts for industrial installations, officials dragged their feet when it came to cultural agreements. ${ }^{19}$

One result of this uneven implementation of cultural exchange was that the number of Soviet films fluctuated from year to year. In 1952, for example, Albania received nine Soviet features (including Taras Shevchenko, The Unforgettable Year 1919, and Country Doctor) and seventy-seven documentaries (among others, Soviet Uzbekistan, Construction Works in Moscow, Ice Dancing, and The Lenin Library). A year earlier, there were twenty-one feature

14. “Arti kinematografik sovjetik, më i përparuari në botë,” Shqipëri B.R.S.S., no. 15 (1948): 26.

15. In 1956, peasants in the Korçë district were said to have discovered India through Soviet newsreels documenting Khrushchev's visit there. "Festivali i filmit sovjetik në fshat," Miqësija, no. 9 (September 1956): 27.

16. RGANI, f. 5, op. 28, d. 153, 1.124 (Levychkin to Zorin [Secret], September 2, 1954). An Albanian source confirms the assessment. Rural film audiences actually declined between 1953 and 1954, due to a limited number of mobile projectors and other equipment failures. AQSH, f. 511, v. 1955, dos. 65, fl. 5 (Relacion mbi çështje të kinematografisë, no date [hereafter n.d.]).

17. On the enduring obsession with rural screenings into the 1960s, see AQSH, f. 490, v. 1964, dos. 378, fl. 3-5 (Vrejtje për një projekt-vendim, August 3, 1964), and (Relacion, forwarded August 22, 1964).

18. Albanian negotiators did not have domestic productions to sell abroad and so relied on the "socialist solidarity" of eastern bloc partners. One official argued that inperson negotiation was the key to obtaining lowered prices. AQSH, f. 490, v. 1952, dos. 1316, fl. 11 (Arts and Culture Committee to Office of Prime Minister, October 23, 1952).

19. When agreements expired in 1951, officials struggled to renew them, thus bringing down the number of imported foreign films. (Only two films were obtained from the "people's democracies" in 1952.) In one example, acquiring a Romanian film took a year, due to delays from diplomatic representatives abroad. AQSH, f. 490, v. 1952, dos. 1316, fl. 12-14 (Promemorie mbi çështjen e filmave, n.d., possibly December 1952). 
films and eighty-seven documentaries. ${ }^{20}$. One major problem with distribution was that Soviet films arrived in a single copy (or sometimes two). This meant that the theaters in the big cities got to screen them first. Only months later did smaller towns, and eventually perhaps some villages, get a chance. It was common for the reels to take close to a year to circulate from one end of the country to the other. This also explains how reels containing documentaries about Lenin, the film Nasreddin $v$ Bukhare (1943), and the classic Chapaev (1934) became so worn out by repeated screenings that replacement was deemed urgent. ${ }^{21}$

The physical exchange of reels was the beginning of a longer process. There were multiple procedures involved, including translation, dubbing, editing, sound mixing, and formulating explanations to go with the films. In the late 1940s and early 1950s, Soviet films were often shown in the original Russian only. ${ }^{22}$ Adding to the problem of a shortage of translators, the regime saw the older intellectual types who might know foreign languages as politically suspect. As an alternative, authorities approached Albanian students enrolled in Moscow universities, who sometimes collaborated with the Albanian-language service of Radio Moscow. ${ }^{23}$ It was one thing to show Russian-language newsreels depicting contemporary events, but how to make sense of feature films in a foreign language? To address the problem, the Friendship Society sent agitators along with the film reels to explain the proper context and meaning of the film to be screened. We are left speculating about the reception of such showings. Unofficial sources are scarce. What existing records do show, however, is

20. AQSH, f. 490, v. 1952, dos. 1316, fl. 12 (Promemorie, n.d). By comparison, in 1948, the country had imported 45 Soviet films and 49 documentaries and newsreels. Figures are drawn from an undated report, forwarded to the Office of the Prime Minister in January 1949, contained in AQSH, f. 490, v. 1948, dos. 811, fl. 12. Soveksportfilm, the Soviet film distribution agency, initially loaned feature films to Albanian enterprises for a period of three years. Contract terms are contained in AQSH, f. 490, v. 1950, dos. 1859. Some of the films made it to Albania soon after their Soviet release, whereas others took years. This was the case, for example, with Efim Dzigan's Dzhambul (1952) and the Georgian Keto and Kote (1948, released in 1953). "Filma të rinj sovjetik në vendin t’onë," Miqësija no. 12 (December 1956).

21. AQSH, f. 513, v. 1950, dos. 18, esp. fl. 18-23 (A survey of film distribution during the period 1945-1950).

22. Albanian-language subtitles made a difference. A translated showing of The Battle of Stalingrad in 1949, for example, reportedly received some 3,000 more viewers than a previous screening in Russian only, even though there were 11 fewer screenings of the subtitled version. Arkivi i Ministrisë së Punëve të Jashtme (hereafter AMPJ), v. 1949, dos. 17/1, fl. 13 (Stamo to Albanian mission [Moscow], n.d.).

23. The Albanian diplomatic representative in Moscow noted that translation jobs encouraged bitter competition among students, who were eager to claim the extra income. AMPJ, v. 1949, dos. 17/1, fl. 5 (Moscow [Prifti] to Tirana, "Rreth përkthimit të filmave Sovjetikë,” received March 31, 1949). Three years later, Soviet films came equipped with Albanian-language opening credits and subtitles, a fact emphasized by the East German representative in Tirana (and seemingly underlined in the memo by officials in Berlin). Politisches Archiv des Auswärtigen Amts-Ministerium für Auswärtige Angelegenheiten (hereafter PA AA, MfAA) A 4.516, 166 (GDR mission [Tirana], "Monatsbericht für August," September 1, 1952). 


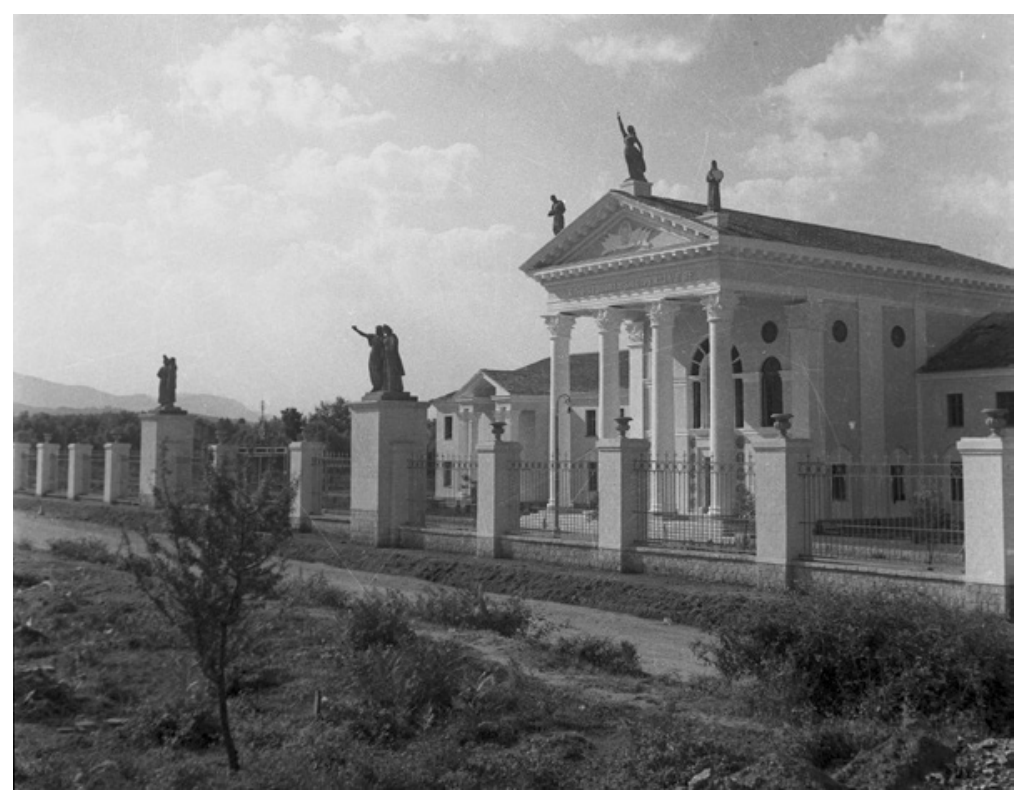

Figure 1. Kinostudio: The Soviet-designed film studio, early 1950s. Courtesy of Arkivi i Agjencisë Telegrafike Shqiptare (ATSH).

an ongoing preoccupation with workers' and peasants' cinematic taste, as well as deliberate attempts to modify it. ${ }^{24}$

At the opening of the Soviet-designed film studio in 1952, for example, Enver Hoxha cautioned filmmakers-almost all of them fresh from courses in Moscow-to go to the people: "Borrow from foreigners what you need and what is best," he cautioned, "but first of all, find inspiration in the glorious and the heroic labor of our people." 25 In a self-conscious move, the studio's first newsreels depicted the construction of the studio itself, lauding "the wonderful architecture of the palace, the beautiful rooms and the complex machines sent by the Soviet Union" (See Figure 1). But this national moment was also clearly marked within an internationalist setting: in addition to agricultural campaigns and military parades,

24. One memo from the Film State Enterprise (Ndërmarrja Shtetërore Kinematografike) to the Albanian mission in Moscow admitted that audiences showed little interest in Soviet technical films. Irritated, the representative in Moscow sent the memo back, warning that such statements were "politically delicate." AMPJ, v. 1950, dos. 31, fl. 113 (Albanian mission in Moscow [Nathanaili] to Tirana, January 11, 1950). Over time, it became increasingly clear that viewers preferred action and comedies. Agitators nevertheless kept taking groups of workers to watch "educational films" like Soviet Azerbaijan. AQSH, f. 490, v. 1952, dos. 1316, fl. 2-3 verso (State Control Ministry, "Raport mbi aktivitetin e Kinematografisë” [Secret], date unclear).

25. The detail stems from the unpublished memoirs of director Endri Keko: "Kinostudio, kujtimet e Endri Kekos dhe këshilla e Enverit për të huajt,” July 11, 2012. at shqiptarja. com/lajm/kinostudio-kujtimet-e-endri-kekos-br-dhe-k-euml-shilla-e-enverit-p-euml-r-teuml-huajt?r=app (last accessed June 4, 2018). 
early newsreels depicted a soccer match with East Germany and a visiting Chinese musical ensemble. ${ }^{26}$

It is also true that referring to "Shqipëria e Re" as a film studio does not capture the full range of its functions. In addition to producing newsreels in the 1950s, it became part of the chain of state institutions responsible for vetting foreign films. The beginnings of a national film industry, then, were closely linked to parallel processes of filtering western products, promoting and distributing Soviet classics, and screening the other nascent national cinemas comprising the Soviet lands, like the Belorussian-produced Deti partizana (1954), or the first Kazakh feature film Poema o liubvi (1954), alongside titles like the Hungarian Állami áruház (1953). "Shqipëria e Re” served as training ground for the country's future filmmakers, who got their start working as second hand to Soviet directors. Beyond training, the studio depended on Moscow for machine spare parts, stocks of negative and positive film, and necessary chemicals like hydroquinone and sodium carbonate. ${ }^{27}$

Exposure to Soviet cinema was one way of attempting to bridge the geographic distance between Tirana and Moscow. This material reliance on the Soviet Union also produced delays, however, and over time, a sense of lagging behind. ${ }^{28}$ Within the circulatory regime of the Soviet sphere, remote Albania became increasingly connected. And yet, precisely the difficulties in translating and disseminating Soviet culture also served as a constant reminder of deficiency. Later Cold War conflicts between Tirana and Moscow have obfuscated the scope of this early internationalism. Because a national Albanian cinema took many years to develop, it eventually became imperative to strip away the multi-directionality of early postwar contacts, to mark the Soviet interventions as alien and unnatural. This made it seem like the national had always been, and necessarily would have to be, in conflict with the socialist international. Soviet-Albanian cinematographic collaboration, however, brings to light the importance of transnational contacts for narrating a national past and present.

\section{Owning the Past: Constantinople to Cannes}

Albania's regime framed the friendship with Moscow as the promise of support against foreign adversaries. The party encouraged a view of Albanians as a fiercely independent lot, surrounded by foes across the border and the Adriatic. There was no better illustration of Soviet engagement with this idea than Sergei Yutkevich's Velikii voin Albanii Skanderbeg (The Great Warrior of Albania Skanderbeg), a biopic of the country's national hero, the 15th century

26. “Zhurnalet e parë të Kino-Studios sonë,” Zëri i Popullit, September 12, 1952, 3.

27. AQSH, f. 490, v. 1952, dos. 1316, fl. 7-8 (Arts and Culture Committee to Office of Prime Minister, dated by hand May 8, 1952); AQSH, f. 511, v. 1953, dos. 83, fl. 80 (Relacion mbi tabelën Nr. 3, n.d.).

28. Soviet-issued film projectors used a type of lamp that could not be found in Czechoslovakia and Hungary. As a result, some film projectors in smaller towns could not be used. Authorities also blamed equipment damage on the unskilled personnel handling the projectors. AQSH, f. 490, v. 1952, dos. 1316, fl. 2 verso (Raport mbi aktivitetin e Kinematografisë, [Secret], date unclear). 
warrior Skanderbeg (Gjergj Kastrioti, in Albanian referred to as Skënderbej). ${ }^{29}$ Cultural authorities were keen on specifically linking the centuries-old stand against the Ottomans with the more recent twentieth century struggles to overcome foreign domination. As a kind of staging of the past, the film also invited Albanians to see their history through "foreign eyes," to witness their claim to national glory from a Soviet perspective.

Yutkevich's film won the International Prize at the Cannes Film Festival in 1954, but that is not the reason why it remains a cult reference to this day. For Albanian viewers in the 1950s, it was the first feature film that dealt with their country. For some, it was the first feature film they ever saw. Moreover, it was action-packed, conducive to mass entertainment. By the 1980s, when state television issued reruns, Skanderbeg had become something of a weathered artifact from a bygone era. The dubbing seemed hilariously poorly executed; Albanian sounds imperfectly superimposed on the moving lips of Soviet actors. But what seemed disjointed in the context of 1980s Albania-by then, Tirana's regime had long abandoned its alliance with Moscow-had once been a signal of cultural progress.

The film was billed as a co-production between Mosfilm and "Shqipëria e Re.” In reality, the local contribution was relatively modest. Soviet partners carried 80 percent of the costs, whereas the Albanian side provided accommodation, transportation, and food. ${ }^{30}$ Filming, which commenced in 1952 and concluded the following year, took place in Moscow and Crimea, but some scenes had to be shot on location, in Albania. ${ }^{31}$ Yutkevich toured Tirana, Krujë, Berat, Gjirokastër, Korçë, Shkodër, and Durrës. ${ }^{32}$ In addition to allocating funds, the government secured locals to serve as extras and old artifacts to be used as props. The shooting, higher-ups told local administrators, was

29. Skanderbeg had emerged as a European reference point long before the advent of communist power, making an appearance in Edward Gibbon's The History of the Decline and Fall of the Roman Empire (1776-89). Antonio Vivaldi had put on the three-part opera Scanderbeg in 1718, whose later productions, as Larry Wolff has shown, signaled rather different things about where Europe began and ended to audiences in Venice and Paris. See his The Singing Turk: Ottoman Power and Operatic Emotions on the European Stage from the Siege of Vienna to the Age of Napoleon (Stanford, 2016), 71-78. The Soviet director thus joined a tradition going back centuries, in which the warrior's military campaign had been cast as a battle between civilizations. See also Oliver Jens Schmitt, "Skanderbeg reitet wieder. Wiederfindung und Erfindung eines (National-)Helden im balkanischen und gesamteuropäischen Kontext (15. -21 Jahrhundert)," in Ulf Brunnbauer, Andreas Helmedach, and Stefan Troebst, eds., Schnittstellen: Gesellschaft, Nation, Konflikt und Erinnerung in Südosteuropa: Festschrift für Holm Sundhaussen zum 65. Geburtstag (Munich, 2007), 401-19.

30. AQSH, f. 490, v. 1952, dos. 544, fl. 2-6 (Kontratë, draft contract between Soveksportfilm and Komiteti i Kulturës, n.d., forwarded June 27, 1952); AQSH, f. 490, v. 1953, dos. 1051, fl. 6-13 (Relacion mbi filmin me ngjyra 'Skënderbeu,' n.d. [forwarded February 5, 1953]).

31. The place to study processes of Sovietization has typically been the borderland of the Soviet sphere, obscuring how, as in this instance, cinematic Sovietization actually may be better imagined as a constant back-and-forth process-occurring, among other places, at the heart of the Soviet Union.

32. PA MfAA A 4.516, 114 (Bericht über das I. Quartal 1953, received April 18, 1953); AQSH, f. 511, v. 1953, dos. 83, fl. 81 (Relacion mbi tabelën Nr. 6, n.d.). 
supposed to become "a mass event." 33 In a display of this collaborative ethos, Soviet author Mikhail Papava wrote the screenplay, but the Albanian party's Central Committee also dispatched the historian Aleks Buda to the Soviet Union to serve as a consultant. ${ }^{34}$

When it came to casting, the main question was this: Who would play the legendary hero? The question was politically significant, and here, too, Soviet authorities expressed the wish that an Albanian actor play the part. ${ }^{35}$ During a visit by a high-level delegation to Moscow, however, a number of Soviet candidates came up instead. The Soviet Ministry of Cinematography suggested names, and Albanian government officials, after viewing auditions, agreed that a Georgian actor-Akaki Khorava-was the most apt for the role. ${ }^{36}$ It is not clear why they preferred him. They may have found the Georgian physically impressive. As one reviewer put it later, Khorava was "dramatic." He had "a giant body." This was important because it allowed the robust actor to present Skanderbeg "as he actually was: big, smart, a distinguished diplomat, a famed strategist, a sworn enemy of treachery, a fiery lover of everything that is beautiful, noble, and progressive." 37

The rest of the cast, which included over sixty Soviet actors, was a kind of microcosm of the "empire of nations." 38 The Georgian actress Veriko Anjaparidze played the role of Dafina. ${ }^{39}$ Oleg Zhakov (from The Great Citizen) played the nobleman Tanush Tapia. Three Albanians played key parts, including Skanderbeg's wife and sister. This multi-lingual casting posed logistical challenges. "I did not understand Russian," recalled Besa Imami, the actress playing Donika, Skanderbeg's wife. Nevertheless, she had found Khorava to be the right man for the job, adding that in his eyes "I saw Skanderbeg in the flesh." The commitment of the Soviet cast, similarly, had demonstrated "the love of the Soviet people for our people." 40 Since actors performed in at least two languages, Yutkevich insisted on strong non-verbal communication, which likely produced some of the exaggerated facial expressions that amused Albanian children watching the reruns in the 1980 s.

33. AQSH, f. 490, v. 1952, dos. 544, fl. 7 (Komiteteve Ekzek. të K.P. rretheve Krujë, Lezhë, Shkodër, Pukë, Tropojë, Kukës, Rrëshen, Burrel, Peshkopi, Elbasan, Berat, Fier, Vlorë, July 21, 1952).

34. AQSH, f. 490, v. 1952, dos. 1316, fl. 18 (Office of the Prime Minister to Ministry of Foreign Affairs, December 24, 1952).

35. AQSH, f. 490, v. 1952, dos. 1316, fl. 1 (Ministry of Foreign Affairs to Arts and Culture Committee [Secret], February 25, 1952).

36. AQSH, f. 490, v. 1952, dos.1316, fl.15-16 (Enver Hoxha to I. Bol'shakov, November 24, 1952); and (Uvazhaemyi tovarishch Predsedatel', November 17, 1952).

37. “Me xhironjësit e filmit me ngjyra 'Skënderbeu,” Miqësija, no. 5 (1953): 19.

38. Francine Hirsch, Empire of Nations: Ethnographic Knowledge and the Making of the Soviet Union (Ithaca, 2005). It should be noted that the Soviet-Albanian cinematic recreation took place alongside choreographed annual "friendship visits" of artists from across the Soviet landmass, including, for example, Uzbekistan's Halima Nasirova and Mukarram Turgunbayeva, and the artists from the documentary Arena smelykh (Daring Circus Youth, 1953).

39. On Anjaparidze’s visit to Albania: "Me xhironjësit e filmit me ngjyra 'Skënderbeu,"” Miqësija no.5 (1953): 17.

40. Besa Imami, “Për herë të parë n’ekran,” Miqësija no. 7 (1953): 19. 
Vahram Papazian played the sultan. Few individuals exemplified better than him the imperial tangle in early twentieth century southeastern Europe. An ethnic Armenian born in Constantinople in 1888, Papazian excelled in Shakespearean roles in the Soviet Union. In a published interview, he admitted that he was not pleased having to play the part of someone "who did so much damage to Albania, but art forces you to act the role of persons you despise."41 Papazian had thus made a full circle-from the Ottoman capital back to the former Ottoman province, but now in the name of the civilizational mission of Soviet socialism. In his early years of acting, he recalled, he had acted in a play by Sami Frashëri (Şemseddin Sami), a playwright who became a key figure in the Albanian National Awakening (Rilindja Kombëtare). Just as later communist-era textbooks would "cleanse" Frashëri from his Ottoman context, so the film in which a Georgian played Skanderbeg and an ethnic Armenian played the nefarious sultan served to detach and prop Albania as a long-standing national unit. If anything, Papazian's physical reemergence, through a 1950s Soviet lens, is a reminder of how empire and nation were interwoven.

When Skanderbeg premiered in Albania, on the anniversary of the declaration of independence from the Ottoman Empire, it was immediately hailed as an historic event. One reviewer praised it for showing the country's contribution to "the defense of European culture from the barbarism of Turkish jeniçerë [Janissaries]." ${ }^{\prime 2}$ But to see Skanderbeg as a product of cultural exchange is to approach it as more than a nationalist ploy. To be sure, the screenplay presented the Venetians as profoundly corrupt, almost comical in their cunning, whereas the Ottomans appeared as wild hordes of barbarians. The film underplayed the warrior's ties to the Christian world, in favor of a more dramatic vision of glorious solitude. Such themes would have been familiar to viewers who might have already encountered Rilindja-era writings about Skanderbeg. But there was something new: the film served as an opportunity to admire the technological modernity of socialism. And that modernity was more immediately visible than, say, promises of future industrial growth.

A big Soviet production, the film circulated in cinemas around the continent, and across the Iron Curtain, from Cannes to Berlin..$^{43}$ Albanian diplomats took pride in this kind of transnational circulation. ${ }^{44}$ Some time later, officials in Tirana screened it during a visit by a Rome-based Sudanese diplomat, who appeared disturbed by how pro-communist fellow Muslims could

41. N. Bulka, "Sa dhe si na njohin sovjetikët," Miqësija no. 1 (January 1955).

42. "Me xhironjësit e filmit me ngjyra 'Skënderbeu,"” Miqësija no. 5 (1953): 19.

43. On East Germany: PA MfAA A 9.474, 43 (Jahresbericht, dated by hand January 10, 1955). On an Italian screenwriter's perspective: Ugo Pirro, Soltanto un nome nei titoli di testa: I felici anni Sessanta del cinema italiano (Turin, 1998), 133-34. Skanderbeg also circulated in several African countries in the late 1950s and early 1960s, thanks to Soviet translation and promotion. I am grateful to Rossen Djagalov for sharing with me excerpts from Rossiiskii gosudarstvennyi arkhiv literatury i iskusstva (RGALI), f. 2918, op. 3-6.

44. RGANI, f. 5, op. 28, d. 153, 1. 136 (Zapis' besedy s poslom Narodnoi Respubliki Albanii v SSSR [Secret], November 12, 1954); Ylli Polovina, “Moska më 28 nëntor 1953 dhe filmi ‘Skënderbeu,’” Shqip, November 28, 2007, 8-9. 
be, and how Stalin's statue in Tirana seemed taller than the local mosque. ${ }^{45}$ Domestically, Yutkevich's film circulated thanks to the mobile projectors of the Friendship Society. Nevertheless, it would have taken months to get the film to the more remote areas of the country. Even as agitators insisted that socialism was harmonizing time across a vast landmass, the reality was that west Europeans saw Skanderbeg before many Albanians had a chance.

The film's circulation shows how Soviet cultural artifacts could be deployed to serve parallel purposes. The Friendship Society, for example, promoted it as a testament of the bond with Moscow, which was said to be e përjetshme ("eternal"). The Society's journal published reportages linking the film's narrative of struggle to the struggle for building socialism. During one screening, in 1956, an elderly peasant from the Bilisht locality was said to have exclaimed: "I would have died in vain had I not seen this film." ${ }^{46}$ Culture officials also recognized the film as an opportunity to project a national narrative abroad. First and foremost, it would familiarize Soviet audiences with Albania-an otherwise obscure country. "Do the Soviets know us, and how?" was the title of one article showcasing Skanderbeg as a device to make Soviet citizens aware of Albania's historical captivity to bigger powers. ${ }^{47}$ This was important given the party's line after 1948: the country stood encircled by enemies on all sides, including Italy, Greece, and the "traitors" in Belgrade. For Albania to be known and taken seriously by the Soviets was not presented as some peripheral concern of cultural diplomacy but a matter of survival.

Yutkevich's biopic signaled another enduring approach of Soviet elites towards the country. In the 1950s, Soviet government officials assumed that Albania had much to learn from republics in the Caucasus and Central Asia, and they drew the parallel by pointing to such factors as religion, a pre-industrial economy, and social conservatism. Nikita Khrushchev would boast that a modernized Albania, in turn, might serve as a kind of example for the Arab world. To be sure, these were Soviet projections, reflecting emerging Soviet global anxieties more than Albanian social realities. The country's political elites did not think of themselves as somehow connected to the Arab world, and they certainly did not think of themselves primarily as Muslims. Still, the notion of Albanians as Muslims toiling for socialism kept resurfacing in conversations and correspondence. ${ }^{48}$ Throughout these contacts between

45. US Embassy (Rome) to Department of State (Confidential), September 16, 1958, in Records of the U. S. Department of State Relating to Internal Affairs of Albania, 1955-1959. Record Group 59, Decimal File 767 (Wilmington, 2002).

46. "Festivali i filmit sovjetik në fshat,” Miqësija no. 9 (1956): 27.

47. N. Bulka, "Sa dhe si na njohin sovjetikët," Miqësija no. 1 (January 1955).

48. Elidor Mëhilli, From Stalin to Mao: Albania and the Socialist World (Ithaca, 2017), 191ff. "But we wanted to help them restructure the Albanian economy," the Soviet party chief later boasted, "bringing it to a modern level, thus making Albania, as it were, a precious gem that would attract the rest of the Muslim world toward Communism, especially in the Middle East and Africa," in Nikita S. Khrushchev, Memoirs of Nikita Khrushchev, vol. 3: Statesman, 1953-1964, ed. Sergei Khrushchev (Providence, RI, 2007), 516. Party officials later denounced Soviet "social-imperialism," but in the late 1950s they readily engaged with the idea of parallels between Albania and the Soviet republics. For instance: GARF, f. 9576, op. 4, d. 1, 11. 118-19 (Predsedateliu Azerbaidzhanskogo Obshchestva Kul'turnoi Sviazi s Zagranitsei, n.d., 1958). 
Tirana and Moscow, Soviet functionaries had the upper hand. But even as borrowed models became commonplace-history textbooks reviewed by experts in Moscow; the country's first comprehensive university emulating a Soviet template-Soviet officials also insisted that Albanians claim their own past.

\section{Owning the Present}

One way of thinking about Soviet-Albanian cinematic contacts in the 1950s, then, is as part of a broader effort to locate the Balkan country within an international map of socialism. To make the country known to outsiders, it was necessary to excavate and accentuate some national differences. Ultimately, however, the point was to spotlight the emerging transnational similarities of socialism, and what better way to do this than by emphasizing themes of occupation and resistance, which transcended national particularities? Like Yutkevich, Soviet director Il'ia Kopalin explored such themes in the documentaries Novaia Albaniia (Shqipëria e Re, 1948), Albaniia (Shqipëria, 1952), and Albaniia, tsveti! (Lulëzo Shqipëri!, 1959). ${ }^{49}$ Clearly, Kopalin’s cine-journalism was of a different genre than Yutkevich's Skanderbeg. Still, it makes sense to view these examples as contextually linked. First of all, both directors anchored the history of Albanian sacrifices and pride on the figure of Skanderbeg. ${ }^{50}$ Secondly, government officials handled these productions in parallel, often referring to them in the same piece of correspondence, as did local press accounts and the Soviet embassy.$^{51} \mathrm{~A}$ number of aspiring Albanian filmmakers and writers, as we will see, worked with these Soviet projects in parallel..$^{52}$

The differences between the two directors are illuminating, too. Unlike Yutkevich, Kopalin engaged with Albania over a longer period of time,

49. Some 77,000 individuals reportedly watched Novaia Albaniia by early 1949 . As is typical with such figures, it is not clear whether multiple viewings by the same individuals were included. The report, forwarded to the Office of the Prime Minister, is contained in AQSH, f. 490, v. 1948, dos. 811, fl. 14.

50. "For two thousand years, Albania suffered foreign occupations," the narrator of Novaia Albaniia offers, adding that "Rome and then Venice tried to enslave it. Byzantium and then Turkey saw it as a door to the Adriatic. Austrians, Italians, and Germans wanted to take possession of this key to the Balkans." One local reviewer praised Kopalin's work for showing "the heroic past of our great-grandfathers, their battles against Roman, Byzantine, Venetian, and Turkish invaders." "Filmi mbi Shqipërinë,” Shqipëri B.R.S.S. no. 12 (1948): 26. The later film Albaniia revisits the theme: "For 25 years, Skanderbeg defended Europe from Turkish barbarism."

51. One example: AQSH, f. 511, v. 1953, dos. 83, fl. 84 (Relacion mbi tabelën Nr. 5, n.d.). For Hoxha, Kopalin's work had "helped enormously in popularizing here and abroad the successes of our people." See the correspondence in RGANI, f. 5, op. 28, d. 153, 1. 131 (Hoxha to CPSU CC, October 22, 1954). Two years later, party secretaries Hysni Kapo and Liri Belishova expressed the wish that Yutkevich and Khorava might become involved with a film on the National Liberation War. RGANI, f. 5, op. 28, d. 391, 1l. 236-37 (Zapis' besedy c sekretariami TsK APT Khiusni Kapo i Liri Belishovoi,” September 25, 1956" [Secret], October 18, 1956). Instead, the 1959 Soviet-Albanian collaboration Furtuna was directed by Yuri Ozerov and Kristaq Dhamo.

52. One Moscow-trained individual recalled getting to know Kopalin and other Soviet filmmakers as a formative experience. Agim Fortuzi, "Si mësuam dhe jetuam në Bashkimin Sovjetik,” Miqësija no. 8 (1953): 21. 
making it possible to observe changes in narrative and focus throughout the 1950 s. ${ }^{53}$ His ethnographic approach has echoes of older Soviet debates over the role of cinema under socialism, and specifically the kulturfilms that had once sought to map the vast and diverse territory comprising the Soviet Union. Decades earlier, in fact, Kopalin had worked with Dziga Vertov's "cine-eyes" group, promoting the "technological superiority of the camera over human vision and the primacy of non-fiction over fiction cinema." 54 Later works included the Stalin Prize-winning war documentary The Defeat of the German Fascist Troops Near Moscow (1942)..$^{55}$ Film scholars might compare the avant-garde years with Kopalin's later output, underscoring a narrowed artistic vision. But it is not the formal qualities that concern me here. Rather, Kopalin's collaborations with Albanian filmmakers reveal how, in a post-1945 world, there was a new socialist territory to be mapped and framed. ${ }^{56}$

The other important distinction here is that compared to Skanderbeg, Kopalin's genre allowed for greater Albanian involvement. Local filmmakers did not yet have the capacity to produce full-length feature films. Documentaries, however, were smaller investments, and some Albanian authors had experience with shorts. ${ }^{57}$ Novaia Albaniia intentionally highlighted this local agency. The poster depicted two beaming local subjects wearing traditional costumes and radiating the redness of the country's flag (see Figure 2, below). It also featured translations from authors Llazar Siliqi and Fatmir Gjata. Stefanaq Pollo served as narrator of the text by Stalin Prize winner Boris Agapov. All three Albanians studied in Moscow. ${ }^{58}$ The Soviet director collaborated again with Siliqi, who authored the text of Albaniia and the screenplay for Albaniia, tsveti ${ }^{59}$ Albanian composers supplied the score. Importantly, another Moscow-trained filmmaker, Endri Keko, who emerged as a central figure of the national film industry, worked on several projects with Kopalin. ${ }^{60}$ In short, collaboration grew over time and across many technical aspects of filmmaking. As the Soviet director toured the country to document its geography-from highland peaks to the birthplace of the party

53. Another Soviet director, Roman Karmen, had directed his own Albaniia in 1945.

54. Oksana Sarkisova, Screening Soviet Nationalities: Kulturfilms from the Far North to Central Asia (London, 2017), 22.

55. Denise Jeanne Youngblood, Russian War Films: On the Cinema Front, 1914-2005 (Lawrence, KS, 2007), 56; Graham Roberts, Forward Soviet!: History and Non-fiction Film in the USSR (London, 1999), 79-90.

56. On the centrality of the Second World War for Soviet-east European co-productions, see Marsha Siefert, "Soviet Cinematic Internationalism and Socialist Film Making, 1955-1972," in Patryk Babiracki and Austin Jersild, eds., Socialist Internationalism in the Cold War: Exploring the Second World (Cham, Switzerland, 2016), 161-93.

57. In its first three years, the film studio produced 37 newsreels and 10 documentary shorts. AQSH, f. 511, v. 1955, dos. 65, fl. 5 (Relacion mbi çështje të kinematografisë, n.d.).

58. Siliqi became a well-known poet and the author of the libretto of the first Albanian opera. Gjata became one of the country's top novelists, whereas Pollo a prominent scholar and political historian.

59. Siliqi is also mentioned in the context of Yutkevich's film. AQSH, f. 490, v. 1952, dos. 1316, fl. 9 (Mbi lëshimin e vizës, August 25, 1952).

60. Endri Keko, “Shqipërija,” Miqësija no. 1 (1953): 9. 


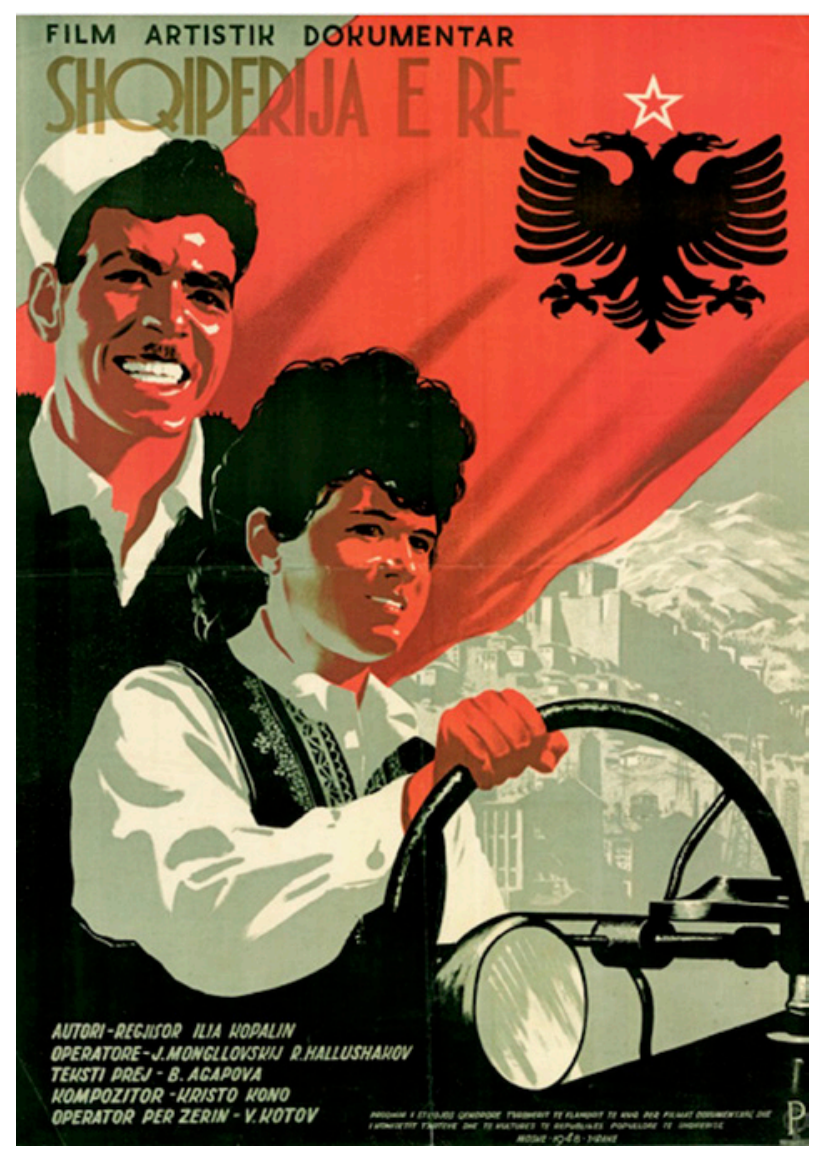

Figure 2. The New Albania: Albanian-language poster for Il'ia Kopalin's Novaia Albaniia (1948). Courtesy of Arkivi Qendror Shtetëror i Filmit. With thanks to Iris Elezi.

leader in the stone city of Gjirokastër-so did his documentaries, by way of mobile projectors. ${ }^{61}$

Compared to Kopalin's earlier works, Albaniia, tsveti! marks a shift in tone. By this point, there had been a decade of construction work on the basis of Soviet material assistance. The focus is not so heavy on the past, but on the championing of a socialist present. The film opens with a sequence celebrating national peculiarities: a man plays the lahuta, the highlander's musical instrument and the mechanism, viewers are told, through which legends have been passed on from ancient times. In a twist, Kopalin and Keko use footage from Yutkevich's Skanderbeg-the genres suddenly intertwined-to underline

61. Screenings in 16 villages in the district of Shkodër reportedly attracted an audience of 3,000 peasants. "Some of them have never seen the Commander [Enver Hoxha] up close," one article observed, "but now they can see and hear him speak.” Kopalin's work was projected on the side of a local building or on cloth hanging from the branches of a tree. “Autokinemaja e Shoqërisë në fshatrat e Shkodrës," Miqësija no. 7 (1953): 28. 
the idea of past resistance to foreign invaders. We see Akaki Khorava furiously riding his horse in the face of Ottoman armies that are actually Soviet extras. Such scenes from the past are fleeting, however. Albaniia, tsveti! is fast-paced, almost in a rush. Sequences give the impression of movement-birds migrating, bullets flying during anti-Nazi campaigns, partisan troops marching-as well as progress: socialism as motion.

This sense of a forward movement is heightened by the camera's shifts. It travels around the country, counting the decade's achievements: new industrial towns like Memaliaj and Cërrik; East German engineers helping with the construction of a copper processing plant in the remote locality of Kurbnesh; oil refineries staffed with Soviet-trained cadres. The harbor in Durrës, where Soviet ships unload their cargo, emerges as a point of contact with the expansive socialist world. Albania was once isolated, the narrator offers, but it is no longer so. Then, the camera leaves the continent entirely, moving to New York. At the United Nations, the country now has a seat (since 1955) and a say in international affairs. Tirana and Moscow may be thousands of miles apart, but "the silver bird" (a shot of an airplane) brings far-flung people closer together. Once, poverty-stricken Albanians would leave their country in hopes of making a meager living under capitalism, in foreign soil (në dhe të huaj). The pain inflicted by economic migration, viewers learn, produced a distinct genre of mournful songs (këngë kurbeti). The film depicts a snippet of such a song delivered by a group of women peering at the sea.

Borne out of despair, the old mobility of kurbet appears distinct from the mobility of socialism, the sign of a distinct modernity. Youths are shown on an upward move, too. A young peasant man has managed to become an engineer. A peasant girl plans to become a teacher. In the city, where these youths study, they attend evening dances. The camera then travels to the villages where these students are from. The film mixes modern elements with scenes of traditional dances, the narrator reminding viewers that in older times, poor girls would have been sold at an early age to a future husband. How could they marry someone they barely knew? Would they be able to make a living? Under socialism, "women do not need to ask such questions any longer." Young couples now enjoy employment, and they can afford to go on vacation. They bring to life healthy, happy children. Still, dangers lurk in the shadows. In an unsubtle juxtaposition, the film cuts from images of children sleeping peacefully to shots of airplanes ready to defend the skies from sudden danger. Soldiers stand guard.

Albania's socialist present is one of mobility and an unprecedented sense of openness. But it is not borderless, Kopalin and Keko remind viewers. The camera travels once more, this time to Moscow, where an art exhibit shows works from different socialist countries, including contemporary Albanian socialist realism. Inevitably, the show features a sculpture of the omnipresent Skanderbeg, crafted by Odhise Paskali. Then, triumphantly, it cuts to Khrushchev's visit to Tirana in May 1959. "All of Albania pulsates like one heart," the narrator declares. The two party leaders are shown giving speeches, Hoxha passionately asserting loyalty to the principles of MarxismLeninism in front of the powerful guest. Chanting crowds fill the city's streets: the climax of a Sovietized Albania. 


\section{The Story Behind the Camera}

Nikita Khrushchev's visit in 1959, however, was not exactly the electrifying success documented in Albaniia, tsveti! Signs of trouble had surfaced earlier, shortly after Stalin's death. One reason for the discord was Khrushchev's pursuit of a rapprochement with Yugoslavia. The Soviet leader also urged his Albanian counterparts to mend relations with Belgrade. For the leadership of the Party of Labor, however, a similar rapprochement was out of the question. Hoxha and his inferiors paid lip service to de-Stalinization, but there was no rehabilitation of political prisoners. On the contrary, their ranks kept growing. Additionally, the uprising in Budapest in the fall of 1956, and the Soviet handling of the crisis, further alienated the Albanian side. When Khrushchev finally made it to Tirana in 1959, the public speeches were exalted. But closed-door conversations betrayed tension. Before his visit, the Soviet party boss had warned that he did not wish Yugoslavia to be brought up, infuriating the hosts. ${ }^{62}$

Albanian higher-ups kept asking Khrushchev for more loans, even as earlier loans had gone unpaid. They were adamant to build heavy industries, but Khrushchev thought that the small country might best serve the socialist bloc as an agricultural supplier. ${ }^{63} \mathrm{~A}$ believer in an international distribution of socialist labor, the Soviet chief did not share the security anxieties of Hoxha and his circle, who obsessed over building a self-sustaining economy, and who were consumed by the idea of being surrounding by enemies. Nevertheless, for all his reservations, Hoxha had no choice but to continue to rely on Moscow. When Khrushchev had delivered his "secret speech" in 1956, there had been grumbling among mid-level apparatchiks, as well as eastern bloc-trained students, who had hoped that some reform might be imminent. Instead, Hoxha presided over a clampdown. Three years later, Khrushchev's visit was an external boost, akin, in the words of the son of a top-level official, to "an emperor coming to town." 64

As Sino-Soviet relations took a downturn in the summer of 1960, these earlier frustrations with Khrushchev resurfaced. Trying to discipline the Chinese, Soviet officials also attempted to get the Albanian party to fall in line. At first, Hoxha cunningly avoided coming out against either party. But neither did he back down when pressured by the Kremlin. For their part, Chinese party functionaries were pleased that Albania supported the Chinese criticisms directed at Soviet policies. Mao deemed that de-Stalinization had been a mistake, and the anti-Yugoslav (and anti-revisionist) rhetoric of the Chinese was warmly received in Tirana. This anti-Soviet turn on opposite sides of the

62. Politburo members fretted that Khrushchev might cancel the visit if they refused to comply with the request. Still, they agreed that their uncompromising stance on Yugoslavia was correct. AQSH, f. 14/AP, Organe Udhëheqëse (OU), v. 1959, dos. 17, fl. 1-6, May 19, 1959, (Protokoll mbajtur në mbledhjen e Byrosë Politike të K.Q. të P.P.SH.); AQSH, f.14/ AP, Marrëdhënie me Partinë Komuniste (b) të Bashkimit Sovjetik [M-PK(b)BS], v. 1959, dos. 18, May 19, 1959, "Shokut Nikita Sergejeviç Hrushov, Kremlin-Moskë” May 19, 1959.

63. AQSH, F.14/AP, M-PK(b)BS, V. 1959, Dos. 24, May 25, 1959, (Protokoll); AQSH, f.14/ AP, M-PK(b)BS, v. 1959, dos. 25, fl. 1-7, May 20, 1959, (Disa kërkesa të K.Q. të P.P.SË [sic] Shqipërisë dhe të Këshillit të Ministrave të shtruara N.S. Hrushçov).

64. Spartak Ngjela, Përkulja dhe rënia e tiranisë shqiptare, 1957-2010 (Tirana, 2011), 240. 
socialist world brought the Albanian and Chinese parties closer together. When Moscow retaliated in 1961, withdrawing Soviet advisers and specialists, Beijing agreed to step in and supply grain and, eventually, factories.

High-level sources provide one angle into the Sino-Soviet rift as political history. But appreciating the social implications of this development requires looking beyond Central Committees, as crucial as they were. In a place like Albania, for example, thousands of people owed their careers to Soviet credentials, their knowledge of Russian, and their professional contacts with the "people's democracies." Many thousands more had attended meeting after meeting, film screening after film screening, where they had heard ad nauseam how the friendship with Moscow was eternal. The friendship now seemed lifeless, raising existential questions about the future. For others still, as we will see, the split seemed like an opportunity for different kinds of alignments: perhaps, eventually, more cultural interactions with the west? In the 1950s, Soviet directors and Albanian propagandists had celebrated a small country's aspiring integration into a socialist world. Now, party directives insisted that Albania would continue to uphold the legacy of MarxismLeninism-against Moscow.

This required remapping the socialist world, without the Soviets at the center. When the Albanian leadership had embraced Stalinism in the 1940s, official decrees had banned Yugoslav literature. In the early 1960s, however, there was no analogous ban on Soviet books and films. On the contrary, propagandists insisted that it was the post-Stalin revisionism that they rejected, not the Soviet Union as a form of a socialist civilization. Therefore, friendship propaganda with the Soviet Union continued for a few years, unreciprocated. The Friendship Society's journal kept reviewing the latest films from Tajikistan, Lithuania, and Uzbekistan. ${ }^{65}$ Even if they had sought to abolish all Soviet cultural influences at once, it is not clear how government officials would have managed to do it. Many of the country's emerging technical elites had graduated from universities in Moscow and Prague. There was a shortage of professional actors and screenwriters. The Soviet Union had furnished the majority of Albania's imported films. Who else could fill the gap? ${ }^{66}$

When it came to money, factories, and weapons, authorities sought assurances in China. Beijing supplied scholarships for local youths who

65. “Çfaqen filma sovjetikë në fshat,” Miqësia no. 6 (June 1962): 28; "Festivali i filmit Sovjetik në fshatrat e rrethit të Pogradecit,” Miqësia no. 8 (August 1962): 13; “Elbasani në muejin e miqësisë," Miqësia no.11 (November 1962); "Nëpër kinostudiot sovjetike,” Miqësia no. 3 (March 1963): 25; “Tre filma të Uzbekistanit,” Miqësia no. 5 (May 1963): 28. The publication's name was modified to Miqësia in 1961.

66. On the importance of central European film schools for Albanian directors, see Artan Puto and Eldon Gjika, "Kinematografia shqiptare midis nostalgjisë, groteskut dhe të ardhmes,” Përpjekja no. 25 (Fall 2008): 7-28. On Prague as training ground for Albanian technicians, see Abaz Hoxha, Ne u shkolluam në Pragë: Intervista, kujtime, mbresa (Tirana, 2003). The shortage of professionally-trained actors continued into the 1960s. (Directors employed amateurs instead.) Soviet equipment, which was still in use by the late 1960s, had become outdated. AQSH, f. 511, v. 1967, dos. 61, fl. 19-22 (Gjendja dhe detyrat për zhvillimin e mëtejshëm të kinematografisë, n.d.). 
could no longer receive training in Moscow, in addition to scores of Chinese advisers. Both countries began to exchange cultural delegations more frequently. ${ }^{67}$ But for all the talk of Sino-Albanian brotherhood, Chinese cultural goods could hardly displace Soviet ones. ${ }^{68}$ For one thing, China was distant, its language unfamiliar. This posed logistical problems, from hurdles of transportation to the tricky problem of translation. Officials and diplomats tasked with gathering Chinese films in the 1960s fretted about this cultural distance, carefully framing it in terms of "comprehensibility." When representatives watched the Chinese film Daji he ta de fuqin (Daji and her Fathers, 1961), for example, they deemed it to have "a healthy educational content." But another Chinese film on resistance against Japan seemed, as they put it, "difficult to understand." 69

Official sources do not allow deeper access into the thinking of intermediaries who made these calls. The precise chain of decision-making cannot always be traced through archival records. Sources do reveal, however, that narrowing opportunities for borrowing after the Sino-Soviet split also raised the political stakes in mapping cross-border exchange. A "healthy educational content" in a Chinese film was politically expedient, but a Chinese film that nobody would want to watch might also turn into a liability. Were there other possibilities? It was possible to expand cultural contacts with North Korea and Vietnam. ${ }^{70}$ Yet these countries could hardly replace the Soviet cultural footprint. As a result, the 1960s reorientation from the Soviet Union, in Albania as in China, happened gradually. Soviet classics continued to circulate for a number of years, with the important distinction that "revisionism" became an increasingly important filter in deciding what aspects of Soviet culture to allow inside national borders.

Another possibility was to purchase films from the capitalist west. The problem here was not simply ideological, though some bureaucrats fretted about western films glorifying "pornography," "murder," and a capitalist way of life..$^{71} \mathrm{~A}$ more immediate concern was the fact that western films, especially the latest productions, cost a lot of money (and required hard

67. AQSH, f. 511, v. 1963, dos. 87, fl. 159 (Plan për zbatimin e marrëveshjes së bashkëpunimit kultural midis Republikës Popullore të Shqipërisë dhe Republikës Popullore të Kinës për vitet 1963-1964, n.d.).

68. Having learned the bitter lessons of the 1950s, the party leadership also sought to keep propaganda for China and Mao under control. For example: AQSH, f. 14/AP, OU, v. 1964, dos. 13 (Proces verbal i mbledhjes së Byrosë Politike të Komitetit Qendror të PPSH [Top Secret], October 31, 1964).

69. AQSH, f. 511, v. 1962, dos. 93, fl. 2 verso (Albanian Embassy [Beijing], Informacion [Secret], forwarded January 25(?), 1962).

70. Administrators also explored markets in Egypt, India, Turkey, and Latin America. See AQSH, f. 511, v. 1962, dos. 93, fl. 2-2 verso (Albanian Embassy [Beijing], Informacion [Secret], forwarded January 25(?) 1962); fl. 5, (Relacion, n.d.); fl. 11-16 (Raport mbi blerjen e filmave kinematografikë, dated by hand June 15, 1962); AQSH, f. 511, v. 1964, dos. 49, fl. 32-33 (Kinostudio to Deputy Minister of Education and Culture, March 9, 1964); AQSH, f. 490, v. 1969, dos. 497, fl. 27-29 (Relacion mbi projekt-planet e shkëmbimeve kulturale në njerëz me vëndet e huaja për vitin 1968, n.d.).

71. AQSH, f. 511, v. 1967, dos. 124, fl. 45 (Relacion mbi punën e bërë në Romë për zgjedhjen e filmave, July 3, 1967). 
currency). Administrators went on state-sponsored pilgrimages to Rome and Paris looking for affordable options. Just as they screened Chinese films for "comprehensibility," officials surveyed French and Italian postwar cinema for "progressive" themes. During one such outing, they suggested picking up a film about Anne Frank, René Clément's The Battle of the Rails (1946), Babette Goes to War (1959), and a film about the indigenous people of New Guinea. They also recommended purchasing Federico Fellini's Nights of Cabiria (1957), with the justification that the movie illustrated the "state of women in capitalist society." Francesco Rosi's Salvatore Giuliano (1962) was deemed worthy for showcasing the "Italian mafia and its connections to government circles." The Italian rural-themed Un ettaro di cielo (1958) and the newer production The Battle of Algiers (1966) also made the list. ${ }^{72}$

A picture that emerges of the 1960s, then, is one of anxiety, particularly in matters of planning and the economy, but also of new possibilities for national assertion within a rearranged socialist world. Just as China helped a small country stand up to the mighty Soviet Union, it also turned into a massive vehicle for projecting Albanian militancy to millions abroad.

\section{Bringing War to China}

Considering that the first full-length domestic feature, Tana-the story of a romance set against the heady years of collectivization-only premiered in 1958, Albanian film production in the 1960 s seems fast-paced. ${ }^{73}$ These films also showed up in Chinese theaters, given the new geopolitical circumstances, dubbed and promoted as the achievements of a friendly state. They included the now-classic Debatik (1961, translated into Chinese as Tamen ye zai zhandou), Detyrë e posaçme (1963), Toka jonë (1964), Vitet e para (1965), Komisari i dritës (1966), Oshëtimë në bregdet (1966), Ngadhnjim mbi vdekjen (1967), Horizonte të hapura (1968), Njësiti gueril (1969), and Plagë të vjetra (1969). The predominant subject was the National Liberation War, with several titles highlighting acts of anti-fascist resistance. Another theme was the construction of socialism, and here too, screenplays centered on struggles-generational conflicts, the battle against backwardness (defined, for example, as the state-led campaign to eradicate blood feuds), self-sacrifice for the collective good, and mass mobilization.

The Sino-Soviet split, and especially China's own internal struggles in the 1960s, endowed such stories of struggle with symbolic weight. The peak of the Great Proletarian Cultural Revolution (1966-1969) was a high point in Sino-Albanian relations. Mao Zedong launched a vicious campaign aimed at

72. Sometimes unable to get private screenings, officials saw the latest films in commercial theaters. See AQSH, f. 511, v. 1967, dos. 124, fl. 46-50 (Relacion për zgjedhjen e filmave dhe blerjen e aparaturave të zërit dhe të stampimit për Kinostudion, dated by hand July 14, 1967) and (Filma që kemi zgjedhur, n.d.). The filing of requests does not mean that they were approved. Moreover, not all purchased films would have necessarily been allowed-or kept-in circulation.

73. For the first time in 1966, the film studio produced two feature films in one year. AQSH, f. 511, v. 1967, dos. 61, fl. 2 (Gjendja dhe detyrat për zhvillimin e mëtejshëm të kinematografisë, forwarded October 20,1967). 
purging the party ranks, attacking the country's elites, replacing "corrupt" officials with more committed ones, and mobilizing China's youths in a revolutionary spirit through Red Guard organizations. At first, these developments disturbed the Albanian party leader, who worried that Mao might lose his grip on power. After reassurances from Beijing, however, the Albanian side heartily supported Mao's campaign in 1967. China's withdrawal from the outside world incidentally helped make the farflung Balkan country politically and culturally relevant. Albanian delegations were allowed privileged access to China, and Mao hailed the Party of Labor as a beacon of MarxismLeninism. In light of these developments, film screenings turned into an important vehicle by which Chinese individuals came to discover a distant Albanian reality.

Chinese propagandists hailed Albania as revolutionary, and its cinema as exemplary and "progressive." ${ }^{74}$ But in thinking about the reception of these films, as was the case with the earlier reception of Soviet productions, it is important to keep in mind the effect of limited competition. At the height of the Cultural Revolution, "revisionist" films became taboo in China. An additional parallel development in both countries-an unplanned commonality-was the late development of television, which helped turn some film screenings into popular events. ${ }^{75}$ In this context, 1960s Albanian films projected an ideologically-acceptable worldview. But equally important is the fact that Albanian films were also opportunities for Chinese viewers to access images from Europe. They "provided Chinese people with an important window," as two authors have put it, "through which to understand the Western world." 76

In 1960s Albania, "the western world" stood for capitalism, of course. Officials would have recoiled at the idea that Albanian cinema was somehow emblematic "of the west." It turned out, however, that Albanian cinematography could also constitute a kind of "ersatz west" under Mao, just like Soviet cinematography in 1950s Albania had served to project a national vision within an internationalist frame. With the seal of official approval, Chinese viewers saw scenes that they might consider to be European modes of living: guitar playing and singing by youthful agitators fighting the Nazis, the dresses of female heroines, and crowded city cafés in the background of the wartime occupation. Socialist states endowed films with political importance.

74. Tina Mai Chen, "Film and Gender in Sino-Soviet Cultural Exchange, 1949-1969," in Thomas P. Bernstein and Hua-yu Li, eds., China Learns from the Soviet Union, 1949Present (Lanham, MD., 2010), 426. For the Cultural Revolution more broadly, see the important study of Roderick MacFarquhar and Michael Schoenhals, Mao's Last Revolution (Cambridge, MA., 2006).

75. Chinese technical assistance in fact helped the government develop regular television programming in the late 1960s and early 1970s. Authorities saw television as a political project and a tool for mass education, but they were also conscious of the danger of western signals, and thus the need for jamming technology, AQSH, f. 490, v. 1972, dos. 390, fl. 11-15 (Mbi ndërtimin e plotë të televizionit tonë me ndihmën e R.P. të Kinës, August 9, 1969).

76. Simon Shen and Cho-kiu Li, "The Cultural Side-Effects of the Sino-Soviet Split: The Influence of Albanian Movies in China in the 1960s," Modern China Studies 22, no. 1 (January 2015): 221. 
Audiences, in turn, promptly scrutinized them for clues about "the other side." Chinese viewers thus discovered glimpses of the west in a resistance-themed story like Ngadhniim mbi vdekjen, which was set during the German occupation and centered on the heroism of two youthful and fearless female characters. On the other side of the globe, Albanian youths looked for glimpses of American life in the Chinese documentary Shijie renmin gongdi (The Enemy of All People), which uncharacteristically attracted a large number of viewers, especially youths. ${ }^{77}$

In the 1950s, Soviet filmmakers had mined the national peculiarities of Albania, within an understanding that socialism was the formula for ultimately giving voice to them. A decade later, those national peculiarities allowed Chinese viewers to look through the scaffolding of socialist realism. As intriguing as such national differences might have seemed, however, we should also consider the power of familiarity. What subjects in the 1960s were easier to understand than war, permanent struggle, and self-sacrifice? These were precisely the themes on offer in Albanian screenplays. Founded by way of Soviet technology and training, the country's film studio projected a specific vision: the notion of defiance. A key difference with earlier Soviet cultural exchanges was that Albania's national character was no longer chiefly articulated through the category of backwardness and aspiration, but through ideas of anti-imperialism and revolutionary zeal.

By the second half of the 1960s, a distinct cinematographic space emerged out of concerns about cultural contamination, party-backed Sino-Albanian cultural exchanges, and the Albanian regime's desire to produce national narratives through film. Whereas Albanian films later found an unexpected life in China, city audiences at home continued to watch older Soviet pictures and a limited range of western titles. ${ }^{78}$ Tirana's moviegoers, for example, were watching Thaw-era films like Two Captains (1957) and Pavel Korchagin (1956), but also older ones like The Story of a Real Man (1948). Some of these had been shown many times before-it was as if Soviet time had stood still in Tirana. Contemporary Chinese films kept circulating too, but they were less popular. A survey of theaters in Tirana found that Soviet films attracted considerably larger audiences than Chinese ones. In fact, almost no Chinese film managed to attract the daily planned target of viewership for the theater in which it was shown. Furthermore, attendance numbers for Soviet films paled in comparison to figures for western ones, with a wildly popular title being The 300 Spartans from $1962 .{ }^{79}$

Why did Chinese films not attract more viewers? One official explained that Chinese directors favored "a manner that our spectator has not gotten

77. AQSH, f. 511, v. 1967, dos. 61, fl. 51 (Informacion. Mbi frekuentimin në çfaqjet e disa filmave në kinematë e Tiranës [Secret], n.d.).

78. The British actor Norman Wisdom would become massively popular in socialist Albania. Film administrators planned on purchasing A Stitch in Time (1963), four years after its release. AQSH, f. 511, v. 1967, dos. 124, fl. 49 (Filma që kemi zgjedhur, n.d.).

79. AQSH, f. 511, v. 1967, dos. 61, fl. 51-52 (Informacion. Mbi frekuentimin në çfaqjet e disa filmave në kinematë e Tiranës [Secret], n.d.). 
used to yet." 80 The feeling appears to have been mutual. Among Chinese film-goers a saying reportedly went like this: "Vietnamese movies are about weapons, North Korean movies are funny and tragic, Romanian movies are romantic, and Albanian movies are utterly confusing." ${ }^{11}$ But it is important to keep in mind that films, whether as sources of confusion or objects of curiosity, were only one facet of a much broader cultural traffic. ${ }^{82}$ To try to make sense of this traffic was to begin to map the cultural borders of non-Soviet socialism, a process bolstered by party-states and national film agencies but not fully commandeered by them.

\section{The Global and the National in Socialism}

When was the birthday of Albanian national cinema? The film studio "Shqipëria e Re" was an important marker, but it also stood as an inconvenient reminder of extensive Soviet influence. Perhaps the origins of a national cinema could be dated back to the nationalization of film theaters in 1947 and the modest newsreels that followed. What about earlier newsreels produced by the fascist-era Istituto Luce ${ }^{83}$ Was a feature film like Tana more national than Yutkevich's Skanderbeg or the collaborations with Kopalin? The Sino-Soviet split rendered such questions ideologically significant. For a regime caught up in some of the defining early battles of a Cold War world, the problem of origin required constant revision. "Our new cinematography is an achievement of our party," one announcement declared, locating the origins of Albanian cinematography in the second half of the 1940s, thus establishing a chronological lineage not bound by collaboration with the Soviet Union. ${ }^{84}$

80. Ibid., fl. 52. In fact, Chinese revolutionary rituals continued to befuddle Albanian visitors. Such confusion needed to be articulated carefully, however, given the political stakes. For examples: AQSH, f. 511, v. 1967, dos. 125, fl. 74 (Ministry of Foreign Affairs to Ministry of Education and Culture, July 20, 1967); and AMPJ, v. 1967, dos. 64, fl. 69-70 (Tirana to Albanian Embassy [Beijing] [Top Secret], September 20, 1967, and September 23, 1967).

81. Quoted in Shen and Li, "The Cultural Side-Effects of the Sino-Soviet Split," 219.

82. Sino-Albanian contacts had been limited before 1960, so state-sanctioned introduction to Chinese civilization was fast-paced. Within a few years, readers were bombarded with everything from the classics to the contemporary-Tang dynasty to Mao Zedong. (The classics, of course, entered through the ideological filters of 1960s Chinese cultural politics.) Translations included Mao's articles on youth (in addition to five volumes of his works), Liu Shaoqi's How to Be a Good Communist (1939), a book on Lei Feng, the poetry of Du Fu, Zeng Pu's A Flower in Sinful Sea, in addition to works by Lu Xun, Mao Dun, Cao Yu, Guo Moruo, and the children's literature of Zhang Tianyi. "Letërsia kineze në gjuhën shqipe," Miqësia no. 10 (October 1965): 6. On both sides, literary exchanges established claims of cultural authority and hierarchy, just as decisions to translate and disseminate (or not) reinforced the idea of an emerging alternative sphere to the Soviet Union.

83. Istituto Luce, Italy's documentary agency founded in 1924, produced numerous newsreels celebrating the making of a fascist Albania. On the origins and the crucial colonial context, see Ruth Ben-Ghiat, Italian Fascism's Empire Cinema (Bloomington, 2015).

84. AQSH, f. 511, v. 1967, dos. 61, fl. 25 (Të dashur shokë e shoqe, [untitled, undated speech filed under the year 1967]). One example serving as a pre-Soviet reference was Komandanti viziton Shqipërin e mesme dhe të jugës (1947), depicting Enver Hoxha touring southern Albania. Ironically, this production had also involved collaboration with Yugo- 
Nationalizing this history of cross-border contacts meant flattening, in retrospect, the geography of socialism, thinning the chronology of circulation, and narrowing the confines of postwar internationalism. Of course, the party-state had specific instruments at its disposal for reordering the past, for remixing the cultural precedents. Managers of the so-called komision $i$ vizionimit could order films out of circulation. Since films were a part of the central plan, bureaucrats controlled what domestic screenplays would see the light of day and what western productions might need to be censored ${ }^{85}$ In a country where fabricated political crimes continued to produce prison sentences, offending directors and actors could be banished, as it later happened with some of the protagonists of Yutkevich's film. In this context, Skanderbeg, which had once helped frame the national heritage, now became a reminder of an inconveniently-tangled past. Similarly, the co-productions with Kopalin fell out of circulation, only to be resurrected half a century later, gaining new life as socialist-era curiosities on YouTube.

When capturing this socialist globalism, a conceptual frame built on a hard distinction between isolation and openness does not work well. Cinematographic exchanges with the Soviet Union in the 1950s could heighten the sense of geographic isolation, for example, just as the selfchosen isolation of Mao's China during the Cultural Revolution created the potential for the largest audience Albanian films ever had. There was no inevitability to some forms of openness, no guarantee that some flows would lead to other kinds of contact, or that they would continue at all. Neither were political breaks neatly aligned with cultural traffic: just as older Soviet films continued to circulate in Albanian theaters after 1961, so Albanian films continued to circulate in China even as the two Communist Parties privately quarreled in the early 1970s on account of Richard Nixon's visit to Beijing. A global telling of the Cold War might discipline the story around political watersheds-1956, 1961, 1972-but it also needs to account for the fact that these obscure the cultural continuity that made the imagination of a socialist future possible.

Interpretations of kombëtarja (the national) in the postwar period, finally, are deficient when they ignore the international staging made possible by anti-fascism at first and, later on, socialism-both in unity and in disunity. These days, Albanian-language newspapers continue to "discover" postwar films, writing about them as if they are the strange relics of a vanished civilization. In fact, precisely because socialist globalism was far-reaching and not easily contained by states, it created emotional attachments that

slav technicians and Avala Film in Belgrade. Later publications mentioned the postwar years but placed the emphasis on the late 1950s. Akademia e Shkencave e RPSSH, Fjalor enciklopedik shqiptar (Tirana, 1985), 268; Abaz Hoxha, Filmi artistik shqiptar, 1957-1984: Filmografi (Tirana, 1987).

85. Calls for a heightened revolutionary approach to filmmaking, already evident in the second half of the 1960s, intensified in 1974, as the party leadership tackled issues of cultural production. AQSH, f. 511, v. 1974, dos. 133, fl. 101-7 (Raport, n.d.). 
transcended official directives and outlived the Cold War. ${ }^{86}$ Chinese individuals of a certain generation not only remember Albanian films, but, as one protagonist recently put it, they "can sing some of the songs from those films, too." 87

86. Ngadhnjim mbi vdekjen has resurfaced, for example, in Xiao Jiang's Meng ying tong nian (Electric Shadows, 2004).

87. "Drita He Daming: Kultura shqiptare, i vetmi dëfrim në kohën e Revolucionit Kulturor,” suplementi Milosao, January 11, 2015. Like “Drita," Zheng Enbo studied in Tirana in the 1960s, and once penned articles about Albanian culture in China's leading paper Renmin ribao (The People's Daily) using the pseudonym "Red Eagle." At the age of 77, he still speaks fluent Albanian. Zheng Enbo, "Shengkai zai Zhong A wenyan li de youyi zhi hua," Beijing Dier Waiguoyu Xueyuan Xuebao 38, no. 4 (2016): 1-9; "Zheng Enbo dhe lidhja e tij e përjetshme me Shqipërinë,” [recorded interview], China Radio International, February 1, 2016, at http://albanian.cri.cn/381/2016/02/01/182s148951.htm (last accessed July 15, 2018). 